\title{
Arboviral Infections around the World
}

\section{Yavuz Uyar*}

Department of Medical Microbiology, Cerrahpasa School of Medicine, Istanbul University, Turkey

In recent years, climatic factors have made various mainly zoonotic and vector-borne agents, known as emerging or re-emerging agents, the most important causes of disease worldwide. Arboviruses are one of the most important groups. Arboviruses (arthropod-borne viruses), such as West Nile Virus (WNV), Crimean Congo Hemorrhagic Fever Virus (CCHF), Sand Fly Fever Virus (SFV) and Dengue Virus, are transmitted biologically among vertebrate hosts by blood-taking vectors, such as mosquito, tick, midge and sandfly arthropods $[1,2]$.

Arboviruses include RNA virus taxa, with more than 550 having been identified, of which more than 130 species can cause infectious diseases [3]. The majority of the Arbovirus genus belongs to the Bunyaviridae, Flaviviridae and Togaviridae families, which are particularly important for public health [1]. The Bunyaviridae family is transmitted both by arthropods (mosquitoes, sandflies, ticks and thrips) and directly from asymptomatic vertebrate hosts (e.g., rodents). Many of these agents are well described and have similar epidemiology [4]. Transmission of Arboviruses can be vertical, while horizontal transmission can be venereal when a vertically infected male directly transmits the virus to a female vector [2]. The most important reservoir hosts for Arboviruses are birds or rodents, while the most important arthropod vectors are mosquitoes and ticks. Generally, Arboviruses require both a vertebrate and arthropod host. Arboviruses breed asymptomatically within arthropod organ and tissue cells. After the arthropod bite, viremia occurs in vertebrate host; arthropods may take virus and transfer to other vertebrate from vertebrate [5].

While Arboviruses are globally distributed, the majority are found in tropical and subtropical regions. In the past two decades, Arbovirus activity and epidemics have increased worldwide [5]. Arboviruses' changing global demographic structure has played a major role in changing the distribution dynamics of Arboviruses diseases [2]. Generally, the human population is exposed to Arbovirus infections when people travel or migrate to rural areas. Recent changes in global climate and other human, epidemiological and genetic factors have increased the need to gather more new data about the emergence of arthropod borne viruses [2].

Gross domestic product per capita and population growth were the main drivers of increases in greenhouse gas emissions, over the last three decades. So, global warming is caused by rising $\mathrm{CO}_{2}$ and greenhouse gases in the atmosphere [6]. During the last decades, Arboviruses such as West Nile virus, Chikungunya virus, Crimean Congo hemorrhagic fever virus, and Sandfly fever virus have emerged to cause epidemics in North America, Europe and Asia [7-11]. For example, WNV epidemics have been correlated with warmer weather and more humid summers in Europe [8], while hantaviral epidemics have been correlated with mast years and rainy seasons in Europe and Minor Asia (Turkey) $[12,13]$. In 2009 and 2010, during particularly warm and humid summers, WNV outbreaks occurred in Russia, Greece and Turkey [14], while sand fly activity increased and sand fly fever epidemics occurred in Turkey $[11,15]$.

In short, global warming and climate instability are playing an increasing role in driving the emergence and redistribution of infectious diseases globally [1]. Such global ecological changes, amount of annual rainfall, intercontinental migration of viral reservoirs (e.g. birds) and economic status of countries may strongly affect the distribution of arboviral infections [7,8]. Therefore, arbovirus infections will remain an important public health problem for a longer period.

\section{References}

1. Cleton N, Koopmans M, Reimerink J, Godeke GJ, Reusken C (2012) Come fly with me: review of clinically important arboviruses for global travelers. J Clin Virol 55: 191-203.

2. Weaver SC, Reisen WK (2010) Present and future arboviral threats. Antiviral Res 85: 328-345.

3. Gao X, Nasci R, Liang G (2010) The neglected arboviral infections in mainland China. PLoS Negl Trop Dis 4: e624.

4. Overturf GD (2009) World arboviruses: the Bunyaviridae. Pediatr Infect Dis J 28: $1014-1015$.

5. Gubler DJ (2002) The global emergence/resurgence of arboviral diseases as public health problems. Arch Med Res 33: 330-342.

6. Metz B, Davidson OR, Bosch PR, Dave LA, et al. (2007) Climate Change 2007 Working Group III: Mitigation of Climate Change.

7. Dimou V, Gerou S, Papa A (2013) The epidemic west nile virus strain in Greece was a recent introduction. Vector Borne Zoonotic Dis 13: 719-722.

8. Fischer D, Thomas SM, Suk JE, Sudre B, Hess A, et al (2013) Climate change effects on Chikungunya transmission in Europe: geospatial analysis of vector's climatic suitability and virus' temperature requirements. Int J Health Geogr $12: 51$

9. Gould EA, Higgs S (2009) Impact of climate change and other factors on emerging arbovirus diseases. Trans R Soc Trop Med Hyg 103: 109-121.

10. Estrada-Peña A, Jameson L, Medlock J, Vatansever Z, Tishkova F (2012) Unraveling the ecological complexities of tick-associated Crimean-Congo hemorrhagic fever virus transmission: a gap analysis for the western Palearctic. Vector Borne Zoonotic Dis 12:743-752.

11. Carhan A, Uyar Y, Ozkaya E, Ertek M, Dobler G, et al (2010) Characterization of a sandfly fever Sicilian virus isolated during a sandfly fever epidemic in Turkey. J Clin Virol 48: 264-249.

12. Ertek M, Buzgan T; Refik Saydam National Public Health Agency; Ministry of Health, Ankara, Turkey (2009) An outbreak caused by hantavirus in the Black Sea region of Turkey, January-May 2009. Euro Surveill 14.

13. Heyman P, Cochez C, Korukluoglu G, Gozalan A, Uyar Y, et al. (2011) Bridging continents; Hantaviruses of Europe and Asia Minor. Turk Hij Den Biyol Derg 68: $41-48$

14. Kalaycioglu H, Korukluoglu G, Ozkul A, Oncul O, Tosun S, et al. (2012) Emergence of West Nile virus infections in humans in Turkey, 2010 to 2011. Euro Surveill 17.

15. 15. Torun Edis C, Yağçı Çağlayık D, Uyar Y, Korukluoğlu G, Ertek M (2010) Sandfly fever outbreak in a province at Central Anatolia, Turkey. Mikrobiyol Bul 44: 431-439.

*Corresponding author: Yavuz Uyar, Department of Medical Microbiology, Cerrahpasa School of Medicine, Istanbul University, Turkey, Tel: 9002124143000; E-mail: yavuz_uyar@yahoo.com

Received December 10, 2013; Accepted December 12, 2013; Published December 14, 2013

Citation: Uyar Y (2013) Arboviral Infections around the World. J Trop Dis 1: e105. doi: 10.4172/2329-891X.1000e105

Copyright: (c) 2013 Uyar Y. This is an open-access article distributed under the terms of the Creative Commons Attribution License, which permits unrestricted use, distribution, and reproduction in any medium, provided the original author and source are credited. 